\title{
REVIEW
}

\section{Ethics, health care and spinal cord injury: research, practice and finance}

\author{
WH Donovan ${ }^{1,2}$ \\ ${ }^{1}$ Physical Medicine and Rehabilitation, University of Texas Health Science Center-Houston, Houston, TX, USA and \\ ${ }^{2}$ The Institute for Rehabilitation and Research, Houston, TX, USA
}

\begin{abstract}
Dating back to ancient times, mankind has been absorbed with 'doing the right thing', that is, behaving in ways approved by the society and the culture during the era in which they lived. This has been and still is especially true for the medical and related health-care professions. Laws and professional codes have evolved over the years that provide guidelines as to how physicians should treat patients, beginning with the one authored by Hippocrates. Only more recently, however, have laws and codes been created to cover health-care research and the advances in health-care practice that have been brought to light by that research. Although these discoveries have clearly impacted the quality of life and duration of life for people with spinal cord injury and other maladies, they have also raised questions that go beyond the science. Questions such as when, why, how and for how long should such treatments be applied often relate more to what a society and its culture will condone and the answers can differ and have differed among societies depending on the prevailing ethics and morals. Modern codes and laws have been created so that the trust people have traditionally placed in their healers will not be violated or misused as happened during wars past, especially in Nazi Germany. This paper will trace the evolution of the rules that medical researchers, practitioners and payers for treatment must now follow and explain why guiding all their efforts that honesty must prevail.
\end{abstract}

Spinal Cord (2011) 49, 162-174; doi:10.1038/sc.2010.106; published online 7 September 2010

Keywords: ethics; morals; health care (research, practice, finance); abortion; euthanasia; academic integrity and spinal cord injury

\section{Introduction}

I am obliged to say at the outset that like most physicians, I am not an ethicist by formal education. In fact, a review of the literature on medical ethics reveals that most authors are not physicians. So I merely bring a perspective of a practicing physician, engaged in clinical research in an academic environment.

Ethics has become a requisite for researchers conducting research with human (as well as animal) subjects in most universities and medical schools throughout the world. Although we now have codified ethical principles to follow in medical research and practice, there are still many areas that come down to using good judgment and common sense in applying these principles.

In researching this subject, I was amazed how many theories have been advanced from ancient times to the present, many conflicting, depending on a number of

Correspondence: Professor WH Donovan, Physical Medicine and Rehabilitation, University of Texas Health Science Center-Houston, The Institute for Rehabilitation and Research, 1333 Moursund Avenue, Houston, TX 77030, USA.

E-mail: William.Donovan@memorialhermann.org

Received 16 April 2010; revised 23 June 2010; accepted 14 July 2010; published online 7 September 2010 factors. Although reading these diverse opinions, I was reminded of some similarities ethics shares with economics.

In 1977, soon after Jimmy Carter was elected president of the United States, he decided to convene and chair a meeting of the world's most learned economists in Washington DC in an effort to formulate a plan that would steer the country away from a financial crisis.

After the first exhaustive day of meetings, Walter Cronkite (1916-2009), reporting the evening news, called on Eric Severeid (1912-1992) to comment on the proceedings. Severeid began his remarks by recalling a previous similar meeting where it soon became clear that there were only two men in the world who really had a complete, comprehensive grasp of the topic of economics. One was British and the other French. 'What did they say?' Cronkite asked. 'They disagreed' replied Severeid.

If you Google the word 'ethics' the search engine will yield over 65 million entries.

Obviously, it is a topic that has inspired many minds throughout the ages, from before Socrates ( $c a$ 469-399 BC) to the present day and demonstrates that over the millennia, mankind has been absorbed with 'doing the right thing'. ${ }^{1}$ 
Any analysis of the works of those who have contributed to the literature on ethics is beyond the scope of this lecture. However, such philosophers include:

Plato (ca 427-347 BC), Aristotle (384-322 BC), Epicurus (341-270 BC) Marcus Aurelius (121-180 AD), Augustine (354-430 AD) Thomas Aquinas (1225-1274), Francesco Petrarch (1304-1374), Thomas Hobbes (1588-1679), Rene Descartes (1596-1650), Baruch Spinoza (1630-1674), John Locke (1632-1704), David Hume (1711-1776), John Gregory (1724-1773), John Stuart Mill (1806-1873) and Immanuel Kant (1724-1804). ${ }^{2}$

In more modern times, names such as Karl Marx (18181883), Friedrich Nietzsche (1844-1900), James Joyce (18821941), Louis Althusser (1918-1990) and Roland Barthes (1915-1980) among many others have written about ethics in the secular realm. ${ }^{2}$

In the spiritual realm, religions have carved moral pathways from books that believers avow are divinely inspired: for Christians - the Bible, for Muslims - the Koran, for Jews - the Torah and Tenach, for Hindus - the Vedas. Other religions have their holy books as well. ${ }^{3}$

It appears that the authors of these treatises and texts are searching for answers to various questions that amount to 'what is the right way to think and behave' in the face of all the vicissitudes of life. The fact that there have been so many proposed theories and doctrines, often conflicting, suggests that mankind, in the pursuit of the virtuous life, has focused not only on theories and doctrines per se but used them to reach a consensus on what is and what is not acceptable behavior in the society and the culture in which the people involved live. Throughout most of history, that 'consensus' was imposed by a monarch or ruler of some sort, by fiat. Today, in democracies, the rules or laws are created by the people through their elected representatives. As Thomas Jefferson (1743-1826) proclaimed to George III of England (1760-1820) in the American Declaration of Independence, governments derive 'their just powers from the consent of the governed'. As the 'governed' are seldom of one mind, the rules and laws in democratic governments reflect what the majority within the society believes is right or ethical and all agree to abide by those rules or seek to change them through the political process.

In like manner, the medical and other health-care professions also have created their own rules of behavior as to what is and what is not ethical within their nation or society. Before I relate how we, in these professions got to where we are today, let me suggest a perhaps novel distinction between ethics and morals, and between laws and codes.

Most texts define and use the words ethics and morals interchangeably, the former being derived from Greek and the latter from Latin. ${ }^{4}$ Although both have as their purpose that of guiding us to act in ways that are good and to refrain from evil, I would suggest that they differ in their mutability.

By that I mean ethics is tied to societal and cultural norms. Therefore, what is considered ethical in one time and place may be unethical in another. For example, among certain tribes in Asia and Africa 'female circumcision' or excision of the clitoris and labia minora is considered ethical while the rest of the world recoils and considers it not only unethical but mutilating. As another example, from the time of Hippocrates (ca 460-370 BC) and before, until recent years, abortion was considered unethical. ${ }^{5-8}$ Now many regard it as ethical. So to some extent what is considered ethical is a reflection of current attitudes of a majority within a society. ${ }^{9}$

Morals or morality on the other hand, I would suggest, in current parlance, is tied to a belief system. Using abortion again as an example, to believers of many faiths including Catholic, Orthodox, and Evangelical Christianity, Orthodox Judaism, Islam, Traditional Buddhism, Hinduism and others, the era or prevailing opinion do not matter; abortion remains (with narrow exceptions, for example, saving the mother's life) immoral. Those who adhere to such belief systems believe their rules or doctrines are divinely inspired and are codified in scripture and confirmed by tradition. Therefore, their views are more refractive to change; for 'how can God be wrong'?

Laws, regardless as to how they are derived, are written rules and also direct us to behave in 'right' or acceptable ways. Failure to abide carries a punishment. Codes, while also written rules, generally apply to specific groups and are agreed on guidelines that apply to that group, for example, the medical profession. Punishment may or may not be attached to infractions. Both are reflections of the ethics and morals that the society or the groups have agreed to abide by.

In a theocratic nation, for example, Iran, or a group like a religious order, these distinctions are blurred, but in a society governed by the 'separation of church and state', the ethics of the majority may differ from the morals of some individuals. In a civil society, if the latter seek to change the prevailing behaviors that the majority considers ethical, they may do so, employing tactics such as debates, essays, blogs, and so on (but never violence) in an effort to persuade the majority to change the relevant laws and/or codes.

This paper will trace the evolution of the codes and laws that have impacted the medical and health-care professions and guided them in ethical ways namely, health-care research and health-care practice and comment briefly on how health care is financed.

\section{Health-care research}

Evolution of the codes of ethics involving research adopted by the medical profession and subsequently by other health professions includes: the Nuremberg Code, the Declaration of Helsinki, the Belmont Report and the Code of Federal Regulations (CFR).

Of these, the Nuremberg Code has the unique role as being the first to clearly define in writing the ethical conduct expected of the medical profession when conducting research on human subjects and also has the richest history. Accordingly, I give it the most attention. ${ }^{10}$

The first of 12 trials of perpetrators of Nazi atrocities, the Doctors' Trial, began in Nuremberg, 9 December 1946 as a military tribunal. Chief Counsel of war crimes, Brigadier General Telford Taylor (1908-1998) and the chief prosecutor for the medical case, James M McHaney (1919-1995), 
thought their task would be easy, given the egregious disregard for human life shown by the Nazi doctors during their experiments. All they had to do was show that the research conducted by the doctors in Nazi concentration camps transgressed the documented rules for human experimentation followed by the medical profession at large. What made his task in fact rather difficult was that there were no such documents. The Hippocratic Oath, the 1803 Code of Medical Ethics authored by the British physician, Thomas Percival (1740-1804), ${ }^{11}$ which was inspired by the works of John Gregory and David Hume ${ }^{6}$ and the 1847 American Medical Association (AMA) Principles of Ethics, ${ }^{12}$ which incorporated much of Percival's work, ${ }^{7}$ dealt with research only vaguely or not at all. In fact, General Taylor discovered that many physicians opposed the creation of specific rules because they felt it would hinder medical research. Nevertheless, a committee (which never met before the trial) was quickly named by Andrew C Ivy, MD (18931978) one of the prosecution's medical expert witnesses, and conclusions composed by Dr Ivy concerning the proper conduct of medical research were presented at trial. ${ }^{10,13}$

In the end, 16 of 23 defendants (20 of whom were physicians) were convicted and 7 were executed. ${ }^{14}$ At the conclusion of the trial, the three judges produced a 10-point document that became known as the Nuremberg Code. ${ }^{15,16}$ This document thoroughly repudiated the concepts of Nazi medicine that were based on the pseudoscience of eugenics, social Darwinism, 'racial hygiene' and other theories of Aryan supremacy that led to making the State the 'patient' rather than the person the patient. In other words, if the interests of the State conflicted with the interests of the individual, the State prevailed. Nearly 50\% of German physicians were members of the Nazi party in 1942 and accepted the idea that involuntary sterilization, involuntary euthanasia and extermination of the 'sub-human population' (that is, Jews, gypsies, Slavs, homosexuals, communists, the disabled and even some intellectuals) could be used to 'purify' the population and the State. ${ }^{17,18}$ It should be noted, however, that such ideas of Aryan supremacy existed in many areas outside Nazi Germany at the time. ${ }^{19-21}$

As the code was not law, many investigators initially ignored it, but over the years, it served as the foundation for the regulations that medical investigators are ethically and legally bound to follow today. Its essential ingredients include: (1) 'the voluntary consent of the human subject is essential'. No coercion, no deceit, full explanation of risks and benefits by the investigator(s); (2) the expectation of gaining useful knowledge; (3) thorough preliminary studies; (4) avoidance of unnecessary suffering or injury; (5) no expectation of death or injury; (6) risks must not exceed benefits; (7) proper facilities are required; (8) only qualified investigators allowed; (9) subject(s) can withdraw at any time; and (10) investigator must terminate the study if harm seems likely. ${ }^{16}$

These principles were written before the birth of bioethics and antedate by 20 years the doctrine of informed consent in the practice of medicine. ${ }^{10,22}$

In 1964, the World Medical Association adopted the Declaration of Helsinki that was also based on the
Nuremberg Code with some modifications. ${ }^{23,24}$ It has subsequently undergone six revisions. ${ }^{25}$ The first revision introduced the concept of independent oversight committees, which evolved into a system of institutional review boards in the United States and ethical review boards (committees) in other countries. ${ }^{26}$ Regulations governing institutional review boards (IRB) came into effect in the United States in 1981 as a result of the Belmont report (see below).

The fourth and subsequent revisions have remained controversial and are no longer followed by the Food and Drug Administration (FDA) in the United States nor by the European Union since $2000 .{ }^{27}$ Instead, they and other countries have adopted the 'Good Clinical Practices', an international set of quality standards provided by the International Conference on Harmonization of Technical Requirements for Registration of Pharmaceuticals for Human Use (ICH) in $2008 .^{28}$

The Belmont Report, issued by the National Commission for the Protection of Human Subjects of Biomedical and Behavioral Research (1974-1978) and also known as 'Ethical Principals and Guidelines for the Protection of Human Subjects of Research' arose from the revelation that the Tuskegee Syphilis Study, conducted at Tuskegee University in Alabama between 1932 till 1972 when it was abruptly halted, had withheld penicillin from African-American subjects although it had been recognized as the standard treatment for syphilis since 1947. ${ }^{29}$ The Belmont Report declared three fundamental ethical principles that should be adhered to when human subjects are used in research: (a) autonomy: that is, respect for all persons, protecting them, treating them with courtesy, respecting their values and beliefs and requiring informed consent; ${ }^{4}$ (b) beneficence: maximizing benefits for the research subjects while minimizing risks to them; (c) distributive justice: ensuring that reasonable, non-exploitative and well-considered procedures are administered fairly, with equity, that is, the fair distribution of costs and benefits to potential research participants while refraining from treating different populations, for example, rich and poor, differently. ${ }^{6}$ This report remains an essential reference for IRB's today. ${ }^{30}$ It is also a significant component of what is today the CFRs.

In 1991, 15 US Federal Departments and Agencies adopted the Federal Policy for the Protection of Human Subjects also known as the Common Rule or 45 CFR 46 of the Department of Health and Human Services regulations. 45 CFR 46 or Title 45 (Public Welfare) CFR Part 46 (Protection of Human Subjects), contains the rules and guidelines that must be followed by all health researchers in the United States today. It is the culmination of all the previous work and contains additional provisions for pregnant women, human fetuses, neonates, prisoners and children that are all deemed particularly vulnerable. 45 CFR 46 also clearly specified the duties of IRB's including the vetting and monitoring of research projects. It is now law in the United States and is required reading for all investigators in the field of human research, including especially, translational research. ${ }^{31,32}$

Recently, the International Campaign for Cure of Spinal Paralysis (ICCP), drawing on the above codes and laws, published a series of four white papers directed specifically at 
the topic of human research aimed at reversing the damage caused by spinal cord injury (SCI). They contained the recommendations of recognized leaders in the field and addressed the subject of ethics in such research along with the principles of randomization, 'blinding', appropriate inclusion and exclusion criteria as well as the generally accepted principles contained in the Belmont report and the other documents listed above. On the subject of ethics they began by saying 'a study involving risks to human subjects cannot be ethically defensible if it is not scientifically defensible.' (I would submit that the converse is also true.) They then expanded on the ethics concerning placebo and sham controls, clear explanation of risks versus benefits, fetal and stem cell research, clinical trials in developing countries and compassionate use protocols.

Finally, the articles expressed caveats to health-care providers and their patients against the lures of procedures currently offered at high prices that despite their claims have demonstrated neither safety nor efficacy in accordance with the rigorous process now accepted by the scientific community. ${ }^{33-36}$

I frequently tell my patients, if or when someone demonstrates a cure for SCI, there is no way it could be kept a secret. The fact that the claims of partial or complete reversals of SCI by entrepreneurs are not accepted by reliable investigators is caveat enough to discourage 'medical tourism'.

\section{Health-care practice}

This brings us to the ethics concerned with the practice of medicine and other health-care professions. Evolution of the codes of ethics involving these professions include the Hippocratic Oath, the most recognized of many medical oaths; ${ }^{5,37,38}$ the works of John Gregory (often referred to as the founding father of modern Western medical bioethical principles) and Thomas Percival; ${ }^{6,7,39}$ the Declaration of Geneva; adoption of the principles of the Belmont Report into clinical practice, namely, respect/autonomy, beneficence and justice to which some have added non-maleficence, that is, avoidance of doing harm; ${ }^{40}$ the creation of ethics committees in hospitals and other health-care facilities and the creation of the Code of Medical Ethics by the AMA. ${ }^{41}$

Hippocrates is said to have lived between 460 and $370 \mathrm{BC}$ on the island of Cos. His oath has undergone many modifications over the years. ${ }^{37}$ If Hippocrates were here today, he would likely be unable to identify the versions currently administered as anything like his own. The original version translated into English ${ }^{5}$ consists of eight brief statements:

(1) I swear by Apollo, the healer, Asclepius, Hygieia and Panacea, and I take to witness all the gods, all the goddesses, to keep according to my ability and my judgment, the following Oath and agreement (that is, invoking deities for a more powerful and solemn promise).

(2) To consider dear to me, as my parents, him who taught me this art; to live in common with him and, if necessary, to share my goods with him; to look upon his children as my own brothers, to teach them this art (that is, respect for mentors and teach students).

(3) I will prescribe regimens for the good of my patients according to my ability and my judgment and never do harm to anyone. (that is, patient comes first; protect him/her). Note: the words 'primum non nocere -first do no harm', which are often incorrectly ascribed to the Hippocratic Oath, are not used.

(4) I will not give a lethal drug to anyone if I am asked, nor will I advise such a plan; and similarly, I will not give a pessary to cause an abortion. (that is, euthanasia and abortion are proscribed). Note: Hippocrates recognized that there were certain cases when abortion was absolutely necessary (to save the mother's life) and knew how to proceed. ${ }^{42}$

(5) But I will preserve the purity of my life and my arts. I will not cut for stone, even for patients in whom the disease is manifest; I will leave this operation to be performed by practitioners, specialists in this art (that is, lead a virtuous and exemplary life and know one's limits).

(6) In every house where I come I will enter only for the good of my patients, keeping myself far from all intentional ill-doing and all seduction and especially from the pleasures of love with women or with men, be they free or slaves (that is, never use one's position to gain favors).

(7) All that may come to my knowledge in the exercise of my profession or in daily commerce with men, which ought not to be spread abroad, I will keep secret and will never reveal (that is, maintain confidentiality).

(8) If I keep this oath faithfully, may I enjoy my life and practice my art, respected by all men and in all times; but if I swerve from it or violate it, may the reverse be my lot (that is, rewards for good practices but punishment for bad).

It is easy to see how much of this oath, now about 2500 years old, still applies today and also how some of it has changed as ethics, itself has changed over time and among different cultures.

These changes were codified by the World Medical Association, an international group of the medical societies of different nations, at a meeting in Geneva, Switzerland in 1948, 1 year after the publication of the Nuremberg Code. The first document, the Geneva Declarations, updated the Hippocratic Oath to conform with modern language. ${ }^{43}$ It has been subsequently amended five times. ${ }^{44}$ It is a declaration of physicians' dedication to the humanitarian goals of medicine. This was felt to be especially important in light of the medical crimes that had been committed in Nazi Germany where nearly 50\% of all practicing physicians were members of the Nazi party. ${ }^{45,46}$ In the latest 2006 version, the subjects of euthanasia, abortion and using influence to gain favors have been removed along with references to a deity. Added are pledges to not discriminate on the basis of 'age, disease or disability, creed, ethnic origin, gender, political affiliation, race, sexual orientation, social standing or any other factor'; also added is a pledge 'not to use one's medical knowledge to violate human rights and civil 
liberties, even under threat'. The product has been criticized as being more vague and general and straying from the Hippocratic Oath, although it contains more items; 11 compared with 8 . In concept and approach, the Declaration of Geneva drew on the World Health Organization (WHO) Constitution $^{47}$ and the 1948 United Nations Universal Declaration of Human Rights. ${ }^{32,48}$

The first recorded administration of the Hippocratic Oath in a medical school setting was at The University of Wittenberg in Germany in 1508. It became part of a graduation ceremony for the first time in 1804 in Montpellier, France. By 1928, only 19\% of medical schools in North America included an oath as part of their commencement exercises. After World War II, this progressively increased because of the Nazi atrocities. ${ }^{49}$

By 1993, 98\% of 157 medical schools in the United States and Canada administered some form of Oath but only 1 used the original Hippocratic Oath while 68 used some version of it. All of those schools using oaths contained a pledge of commitment to patients, only $43 \%$ contained a vow to be accountable for one's actions, 14\% included a prohibition against euthanasia, 11\% invoked a deity, 8\% prohibited abortion and only $3 \%$ prohibited sexual contact with patients, something that I daresay Hippocrates and John Gregory would have found surprising. 4,7,50,51 The study has not been repeated recently.

The physician of today, however, regardless of the kind of pledge, he or she does or does not make on graduation, enters a milieu wherein acceptable and unacceptable patterns of behavior are now more clearly identified. Owing to the documents cited earlier, particularly the Belmont Report that targeted medical research but apply to medical practice as well, namely autonomy, beneficence and justice, many nations have developed position papers on topics that fall within the ambit of these principles. For example, in the United Kingdom, the General Medical Council provides clear overall guidance in the form of its 'Good Medical Practice' statement. ${ }^{52}$ In the United States, the AMA's Council on Ethical and Judicial Affairs (CEJA) has produced the 'Code of Medical Ethics'. ${ }^{53}$

Documents such as these provide guidance for practitioners, primarily physicians practicing in these countries. The British version addresses such issues as (a) euthanasia and related topics such as complex end of life issues including relief of suffering; the so called 'double effect' in which a drug such as morphine may relieve pain, but suppress respiratory drive; 'futile care' in which prolonging life only prolongs suffering with no hope of recovery; (b) confidentiality, and related topics such as notification of authorities if a physician believes the patient is about to do harm to him/herself or another; parental notification; (c) conflicts of interest and related topics, for example, referrals, vendor relationships, business practices and truth telling. It also emphasizes the importance of ethics committees.

The AMA publication goes even further, providing ethical guidance based on Council opinions and case law on many topics. In over 200 pages, it deals with seven basic principles that should govern a physician's behavior: (1) competence and compassion, (2) honesty and patient protection, (3) patient advocacy, (4) confidentiality and patient rights, (5) physician continuing education, consultation when needed, patient education, (6) freedom for the physician to choose with whom to serve and associate and (7) community service. Within that framework, eight chapters deal with council opinions and judicial rulings on (1) social policy, including abortion, futile care, capital punishment, organ donation, euthanasia and physician-assisted suicide among others; (2) professional relations dealing with allied health professions; (3) hospital relations including contractual relations, billing for house staff and student services; (4) confidentiality, advertising and media relations including most of the areas addressed in the Health Insurance Portability and Accountability Act; (5) fees and charges including fee splitting, professional courtesy; (6) record keeping; (7) practice matters including consultations, conflict of interest, gifts from industry, informed consent, termination of the doctor-patient relationship, among others and; (8) professional rights and responsibilities including ethics committees, medical testimony, caring for the poor among others. Many examples are offered with explanations as to how decisions were reached by the council or the courts. It is a very useful document for practitioners in dealing with complicated issues and for ethics committees to help guide their deliberations. ${ }^{53}$

These documents have helped answer the concerns expressed by Pellegrino in 1976 that physicians were becoming so absorbed with technology and reimbursement that humanistic values and 'sympathy', as described by Hume, and honesty and non-paternalistic treatment as described by Gregory and Percival, were becoming lost. ${ }^{6,39,54}$

\section{Health-care financing}

The ethical considerations attached to how medical care is financed, is equally relevant for consumers and providers. Methods of payment vary throughout the world but basically are:

(a) Direct payment from the patient to the provider.

(b) Government payment for part or for all costs.

(c) Private third-party insurance payment for part or for all costs. 55

Although direct payment may be feasible for all costs if the cost is 'affordable', it can easily be beyond the reach of consumers as costs rise and more care is required. So, most people require help from the government or private insurance beyond a 'deductible' or 'co-pay'.

The principle behind health insurance, like other insurance is: you pay a premium you can afford for a service you hope you'll never need so that if you ever do need it, you can have it for a cost you can afford. Unlike sweepstakes, it is the unlucky ones who get to take out more than they put in, thereby avoiding financial ruin. In order to have the resources to meet the needs of the 'unlucky ones' with big health-care costs, there must be a sufficiently large number 
of 'lucky' consumers with no or low health-care costs in order to keep premiums low enough for everyone to afford.

For those locations and populations where the government pays the provider, the government can manage the required premiums or contributions by taxing the entire citizenry and by limiting what it pays providers and what treatments it will pay for.

For those locations where private insurance exists or co-exists with government, premiums can also be managed by raising or lowering them, by limiting payments to providers, by refusing or discontinuing those patients deemed to be high risks of loss, by steering patients to providers who provide less care or provide care for less cost and in addition, by using capital raised from 'good' investments to offset the needs to raise premiums. However, this last option can work the opposite way in bad times.

Ethical questions arise when private insurers, including those working as 'intermediaries' or essentially contracted administrators for the government, must decide to authorize or not, payment for treatments that providers say is necessary. Denial of such authorizations are common nowadays in some countries and raise concerns when requests for new medications, durable medical equipment, quality of life enhancing treatments and even some surgical procedures are denied by insurers and their company medical advisors, often on the grounds that there is a lack of medical necessity, although these advisors are often considerable distances away from the patient and have never seen much less examined him/her or spoken with the family. ${ }^{56-59}$

It becomes necessary to recognize a dichotomy in the application of insurance. To the provider, the patient's interests come first. To the insurer, the patient's interests must be weighed against the company's interests, which include other patients' claims and profits for employees, investors and executives.

In addition, providers are bound by oaths, codes and laws to put the patient's interest first not the 'State's' or the payer's. Insurers are not. Although the government is also not thusly bound, the money 'saved' from the denials by private insurers follows a different path from that of governments. When providers and the public see the profits of the insurers, particularly when they are deemed excessive, go to company executives and investors instead of being used to lower premiums, cover high-risk consumers and provide authorizations for needed treatments, they cannot help but conclude there is a conflict of interest and question the ethics of those companies, particularly if their medical consultants are paid based on the number of requests they deny. I hasten to add this behavior does not proceed from all insurers but happens enough from some to raise concerns and forces the public's attention on the thorny issue of the rationing of care. Many nations already live with the fact that despite respect for patient autonomy and beneficence, payment for some aspects of care cannot be afforded. Although difficult, this can be more readily accepted if the principle of distributive justice has been applied equally to all, avoiding unfair selectivity ('cherry picking') and discrimination by payers and providers. ${ }^{4,60,61}$
But on the other hand, when providers overcharge or engage in fraudulent behavior when billing the government or the insurance company, their breach of ethics is just as serious as the payer's and may also break the law. And finally, when consumers try to persuade providers to prescribe things they don't really need and would not purchase even if they could afford them if they had to pay for it themselves, this also raises questions about a breach of ethics on their part.

It seems clear then, that honesty in regard to complaints, care and compensation would solve many issues related to ethics in health care, a point made by John Gregory over 200 years ago. ${ }^{39}$

\section{Relation of the foregoing to $\mathrm{SCl}$}

Among the many topics in these documents that fall within the ambit of medical ethics, I have chosen three that have special relevance nowadays to the field of SCI: (a) abortion because of the issue of the use of human embryonic stem cells in research; (b) euthanasia because of the issue of the value of life and quality of life for the disabled and elderly and; (c) academic integrity because of the hope and faith that translational research will yield fruitful results.

\section{Abortion}

The morality (as defined above) and efficacy of the use of human embryonic stem cells as well as the efficacy of human adult stem cells and other cells including olfactory ensheathing glia for SCI, remain a matter of debate. Excellent reviews of this topic concerning the scientific aspects have been published. ${ }^{62-64}$ Although most scientists would not deny that removing a fetus equates to abortion or some synonym of it, for example, termination, most have avoided the moral aspect, relegating that to ethicists and jurists. In this discussion, it is not my intent to take sides in the 'choice versus life' debate, but only to examine the issue in the light that science has now provided us.

As one might expect, the debate over abortion did not originate with Hippocrates. Laws concerning abortion were mentioned in the Code of Hamurabi, ca 1760 BC. ${ }^{65}$ The first recorded evidence of induced abortion is from the Egyptian Ebers Papyrus in ca 1550 BC. ${ }^{66}$ Since then, from ancient times to this day, advocates have used various methods to induce expulsion of the fetus such as: physical: (strenuous exercise, massage and paddling); pharmacological agents: (abortifacients, for example, hellebore, tamsy, bithwort and myrrh); devices: (for example, pessaries) and surgical procedures: (for example, blood letting, dilation and curettage) to mention a few. ${ }^{67}$ Abortion remained a dangerous procedure into the early twentieth century. Of the estimated 150,000 abortions that occurred annually in the United States during the early 1900's one in six resulted in the woman's death. ${ }^{68}$ The risk of maternal death when weighed against the benefit expected surely had a role in the decision of many countries and regions within countries to ban it before the midtwentieth century. The opinions of many who opposed it on moral grounds, for example, Thomas Aquinas (1225-1274) ${ }^{69}$ 
and political grounds, for example, Susan B Anthony (18201906), Elizabeth Cady Stanton (1815-1902) and Horace Greeley (1811-1872) also had a role. ${ }^{70}$ It is interesting that early women' rights advocates were opposed to abortion while later ones have favored it.

It is also interesting that Nazi Germany's laws allowed for abortion only under tightly controlled conditions, namely if the mother was believed to carry a fetus with a hereditary disorder, as long as it was not yet 'viable' (generally equated with quickening) and if she gave her permission. Otherwise, it was forbidden. ${ }^{71}$ In 1939, the Journal of American Medical Association reported two German high court decisions regarding the law restricting abortions. The court ruled that the restriction even applied to Jewish women (and I quote) 'however undesirable the birth of Jewish children might be'. ${ }^{72}$ By 1939, under Adolf Hitler (1889-1945), all vestiges of the Weimar Republic had vanished. It is hard to imagine even the high court ruling in a way opposed by the absolute dictator, a man who had no compunction at all about killing Jews who had already been born. But it indicates the generally prevailing sentiment among most nations against abortion at that time.

However by 1973, the United States Supreme Court took an opposing view, ruling that a person's right to privacy and due process under the 14th Amendment of the US Constitution allowed her to abort her fetus. Although Justice Harry Blackmun (1908-1999) writing for the majority (seven to two decision), wrote a thoughtful and well-researched decision, neither he nor the other justices could have known much about the potential of DNA, let alone its future uses in forensic medicine and for purposes of establishing identity. ${ }^{73}$ Watson and Crick $^{74}$ had only reported this discovery in 1953 in the scientific journal, Nature, and much more was yet to be learned about it. We know that the penetration of a human ovum by a human sperm initiates a process that will produce a mature human being unless interrupted by natural or unnatural means. Both the ovum and the sperm contain human DNA and the resulting zygote contains human DNA. Thus, once a haploid ovum has been penetrated by a haploid sperm, forming a diploid zygote, proof of its viability is provided by its cellular division; thus human DNA now has human life. Whether one is discussing a seedling, a larva or a mammalian embryo, clearly the object is in a different form from the mature one it will become, yet the DNA remains the same.

Justice Blackmun based his ruling on the supposition that the fetus 'becomes human' at some point during gestation. Knowing what we know now about DNA, such arguments would appear sophomoric. I would submit to you that perhaps we have taken the polemic in the wrong direction and what we should be discussing is when is it ethically permissible for one or more members of a society to extinguish the life of one or more other members? Situations that would clearly not be permissible include murder while situations that would clearly be permissible include killing in self-defense. Those aside, I submit that there are four situations, the ethics of which fall within the ambit of this question namely: abortion, euthanasia (voluntary or 'doctor assisted'), judicial executions and warfare. All involve the extinguishing of human life. I would not be surprised to learn that some people might take an advocacy position on one of the four and an opposing position on another, depending on one's culture, education and beliefs. Or in some instances, people have decided that only if certain thresholds were exceeded, would it justify the taking of human life. For abortion, such thresholds have included: protection of the woman' life, her physical health, her mental health, rape, fetal defects, socioeconomic factors and 'convenience'. Views on all of them differ from nation to nation - from Chile and others where none justify abortion to Iceland and others where all do, further highlighting the fact that what is considered ethical cannot be applied worldwide because of the influence of cultural differences discussed above. $^{75,76}$

\section{Euthanasia}

The primary focus of health care has always, quite rightly, been the saving and the improving of the quality of life. Such 'quality' at the 'end of life' has recently gained more attention, difficult to discuss as it may be.

The depression that follows SCI and its influence on quality of life and on the effectiveness of coping mechanisms has been well documented. ${ }^{77-79}$ Suicide has crossed the minds of some persons with SCI at some point during their lives. A recent survey by Kennedy et al. ${ }^{80}$ reported nearly $50 \%$ of those responding expressed overall dissatisfaction with life during the early post-injury period. In 1991, a study revealed suicide was 10 times more likely among those with SCI during the first 5 years post-injury but after that, the incidence was equal to the general population. ${ }^{81}$ The US National Spinal Cord Injury Statistical Center at the University of Alabama, Birmingham recently reported that among the causes of death of 9774 persons with SCI, suicide was the cause for between 3 and $4 \%$ and ranked as the eighth or tenth most common cause, depending on the way the data were analyzed. ${ }^{82}$ Yet also documented is the difference between the desire by patients to go on living and the perception of that desire by their caregivers; the former being higher. ${ }^{83}$ In the discussion that follows, the term euthanasia is used in the broadest sense, referring to end of life issues in general that patients and their families sometimes inquire about but providers are often reluctant to bring up because to many, it connotes a failure: of the patient to cope and/or the providers to provide adequately. So the topic would seem appropriate to include in a discussion on ethics.

Although Hippocrates also enjoined physicians to refrain from euthanasia, it was not uncommonly performed in Greek and Roman times. The word itself, comes from the Greek 'eu' — good and 'thanatos' — death, that is, dying well.

Euthanasia conducted with the patient's consent is termed voluntary euthanasia. Euthanasia without that consent is termed involuntary euthanasia. In medical circles, the latter is generally construed to mean it is conducted when another individual makes the decision for the patient when he/she is incapable of doing so and clear authority has been delegated by the patient to a specific individual to make that decision. Historically, as noted below, the term has carried other more 
sinister connotations wherein neither the comfort of the patient nor the patient himself is the driving force. ${ }^{84}$

Euthanasia may also be passive or active, primarily based on whether an intervention to hasten death is or is not taken. ${ }^{84}$ In those locations where it is legal, it is passive voluntary euthanasia that is usually practiced, although it is generally not labeled as such, because of the connotation of the word. Beyond simply 'letting nature take its course', this usually entails, (a) the withholding or withdrawal of common treatments, that is, medications or surgery either because risks outweigh benefits or because of patient wishes, expressed either directly or by a living will, or (b) by the administration of treatments that have a 'double effect', for example, morphine given to relieve pain despite its risks of suppressing respiration. In general, this form of euthanasia does not carry a pejorative connotation and is practiced in many hospitals under the guidance of ethics committees and advanced directives especially when issues of deteriorating quality of life, insufferable pain, futility of further interventions and devastating co-morbidities loom large. ${ }^{85}$

The courts and ethics committees in many nations have generally approved the withholding or withdrawal of life sustaining medical treatment in which the treatment 'serves to prolong life without reversing the underlying medical condition' ${ }^{86}$ Under the principle of autonomy, as defined in the Belmont Report, the physician should respect the patient's decision to such withholding of treatment as long as he/she possesses decision-making capacity. The AMA CEJA states that the same applies even if the patient is incompetent or unconscious if he/she has formulated an advanced directive indicating a point in which treatments such as 'mechanical ventilation, renal dialysis, chemotherapy, antibiotics and artificial nutrition and hydration' among others are not desired. It further states that the patient's or the patient's duly appointed surrogate's wishes should always be respected except '(a) when there is no available family member willing to be the surrogate decision maker, (b) there is a dispute among family members and there is no decision maker designated in advance, (c) a health-care provider believes that the family's decision is clearly not what the patient would have decided if competent and; (d) a health-care provider believes that the decision is not a decision that could reasonably be judged to be in the patient's best interest. These situations should be referred to ethics committees for resolution before resorting to the courts' ${ }^{86-87}$ In the United States, it was the decision rendered in the Karen Ann Quinlan (1954-1985) case that influenced much of public opinion in favor of legal protection for voluntary passive euthanasia. ${ }^{88}$ Thus, lately, the courts have generally ruled that when the patient is unconscious (for example, persistent vegetative state) or incompetent, that it is ethical to withhold life sustaining measures as was the case with Terri Schiavo (1964-2005). ${ }^{89}$ In 1997, the Philadelphia County Court issued a declaratory judgment that a conscious patient was entitled to the same right under the principle of autonomy. ${ }^{90}$

Active euthanasia on the other hand entails the use of lethal substances or forces to end life and includes the topics of physician-assisted suicide and so called 'mercy killing' ${ }^{84}$
In this regard, several nations, including the Netherlands and Belgium and states within Australia (Northern Territories) and the United States (Oregon and Washington) have passed laws legalizing physician-assisted suicide. In fact, the Oregon Death with Dignity Act states that active voluntary euthanasia (in the form of 'doctor-assisted suicide') as performed under the Act, '... is not suicide so should not affect insurance by that definition'. ${ }^{91-94}$ Most government entities, however, have relied on court rulings and the opinions of national ethics committees such as the General Medical Council in the United Kingdom and the AMA's CEJA in the United States. For example, in Great Britain, in 1957, the court ruled in the trial of Dr John Bodkin Adams (1899-1983), that 'causing death through the administration of lethal drugs to a patient, if the intention is solely to alleviate pain, is not considered murder, even if death is a potential, or even likely outcome'. ${ }^{95-96}$ In Switzerland, in 1937, doctor-assisted euthanasia was declared legal as long as the doctor ending the life had nothing to gain from it. ${ }^{97}$ Nevertheless, although court rulings and opinions have varied, they have generally disapproved of voluntary euthanasia in the form of doctor-assisted suicide, regarding the principle of patient autonomy to be outweighed by concerns over the lack of clarity and consensus about the ethics of it which have been viewed by the courts as a proper concern of the State where intervention to end life must be balanced by commitments to 'first do no harm' or non-maleficence. This issue is likely to evolve further over time. ${ }^{86-93}$

However, it is the involuntary and active form of euthanasia (ending one's life without one's consent) that has generated the most concern over a 'slippery slope' by raising the question, where in any given culture, will the line be drawn (between voluntary and involuntary euthanasia) so that once crossed, involuntary active euthanasia would be considered ethical, and who will be making the end of life decisions if not the patient or family? Just as for voluntary euthanasia, this is especially important to consider when the patient is not on life support and does not have a terminal illness, so these factors are not present but he/she does have an incurable condition. ${ }^{86}$

This concern over the 'slippery slope' does have historical relevance, most notably during the Nazi control of Germany's Third Reich when voluntary euthanasia devolved into involuntary euthanasia when about 70000 disabled people were put to death between 1939 and 1941. The Nazis justified this by saying the country, left financially crippled by World War I, could not afford to treat people with chronic physical or mental illness; instead all had to focus on staying well. This pogrom came to a halt largely as a result of the sermons and writings of the Catholic archbishop of Munich, Clemens von Galen who condemned the carnage. The text of this sermon was duplicated and copies were distributed throughout Germany and occupied territories and reached the troops fighting on the Russian front. To them, von Galen directly addressed the terrible question as to what they might expect, if wounded and permanently disabled, from a nation that took the lives of people that were no longer capable of being productive. Hitler, weighing the political 
consequences, in a rare display of acquiescence, called the pogrom to a halt. ${ }^{98-99}$

Now, involuntary active euthanasia is illegal in all countries of the world except in the Netherlands, where it is practiced under an agreement between physicians and district attorneys that was ratified by the Dutch National Associations of Paeditricians under the Gronigen Protocol, which applies only to certain deformed newborns, with parental consent. ${ }^{100}$

Although events that occurred under the Nazi regime or during the Tuskegee research project could not happen again in most nations throughout the world, it is nevertheless understandable if people with chronic conditions such as SCI get a little bit nervous and carry a haunting and often silent suspicion when their leaders start talking about reducing the cost of health care and they worry that someone in power will make an unfavorable value judgment about continuing to fund the treatment they need to sustain life as well as quality of life. They worry that the issue of cost will supersede distributive justice.

My patients tell me that it's not that a person with a disability or their loved ones object to talking about end of life issues, it's just that decisions about if, what and when treatment should be withheld or when further treatment would be futile or whether the process of dying should be 'helped along' or whether organs should be donated, and so on are personal, voluntary decisions and should remain so, as they are now, and should not be made by legislators or bureaucrats far removed from the persons who could be affected by that legislation.

Thus, it is with some justifications that organizations such as CEJA advise caution and clear guidelines allowing for autonomy, beneficence, non-maleficence and justice if or when voluntary doctor-assisted suicide is sanctioned. ${ }^{86}$

\section{Academic integrity}

This term is often used when referring to cheating by students in the classroom setting and how it can be discouraged. Hinman ${ }^{101}$ has emphasized the virtue of honesty to others and to one's self. He gives the following example to his students at the outset of the course he is teaching: a student cheated undetected on all the quizzes and final exam, receiving a 98\% grade. When the final marks were posted, he was shocked to see he had gotten a D. When he confronted the teacher, asking how he received the $\mathrm{D}$ when his marks should have earned him an A, the teacher replied 'I know what you are saying but I lied to the provost about your grades and she gave you a D'. 'You lied'? The student asked dumbstruck. 'You can't lie about my grades'. 'Why not?' replied the teacher. 'You did.'

The main reason why cheating as a student should not be tolerated is that research and practice in the health sciences abjure dishonesty of any kind because of the potential harm it can bring to people's health. Thus, dishonesty should never become a part of a professional's or future professional's behavior. It is the behavior of the professionals, both established and aspiring that concern us here.

Although many nations have taken steps to ensure such honesty, I shall use those taken in the United States as examples.
The Office of Research Integrity (ORI) in the US Department of Health and Human Services has published what it calls 'points for discussion', which addresses many issues including research misconduct, institutional responsibilities, conflicts of interest, the research environment, collaboration, data management and scientific journals among others. ${ }^{102}$

Unlike research subject recruitment and patient treatment for which we now have codes and laws, as noted earlier, these topics deal more with how discoveries are documented and disseminated. Yet they have just as great a ripple effect on society because societies expect that researchers will truthfully report what works, seems to work, seems to not work, and doesn't work at all and they trust that practitioners will truthfully convey that information to their patients.

However, King ${ }^{103}$ has stated that in one sense, researchers themselves should not 'trust' each other, meaning that all research data, including raw data, should be open to scrutiny by colleagues so that the work can be reproduced and its rigor verified.

Failure to allow one's evidence to be examined by colleagues simply encourages suspicions of research misconduct. The National Academy of Sciences (NAS) has aptly addressed possible reasons for research misconduct: '(a) funding and career pressures of the contemporary research environment; (b) inadequate institutional oversight; (c) inappropriate forms of collaborative arrangements between academic scientists and commercial firms; (d) inadequate training in the methods and traditions of science; (e) the increasing scale and complexity of the research environment, leading to erosion of peer review, mentorship and educational processes in science and; (f) the possibility of misconduct in science is an expression of a broader social pattern of deviation from traditional norms'. ${ }^{104}$ The Scientific Research Society has stated that a common avenue to research misconduct is through statistics - either through carelessness or dishonesty, for example, 'bending' the data to conform to a preconceived outcome or expectation. ${ }^{105}$

The ORI points out that responsibility for maintaining honest and transparent research lies with several entities: (1) the scientists and their scientific societies should adhere to honest reporting and collegial scrutiny of their colleagues' work. The scientists, particularly the principal investigators are, along with their institutions, responsible for the research environment in which carelessness, apathy or fraud cannot be tolerated. This applies not only to the conduct of the research but to other aspects as well such as honest timeeffort reporting and full disclosure of funding sources; (2) the institutions themselves are also responsible for the research environment. ${ }^{102}$ According to the Institute of Medicine (IOM), institutions 'need to demonstrate more active interest in assuring faithfulness to the ethics and ideals that already form the foundation of the ethics of science in the academic sector' and 'need personnel who think critically about the integrity and quality of the research environment and ways in which it can be improved'. ${ }^{106}$ The NAS has also advised that the institution is responsible for 'ensuring that good 
scientific practices are observed and that balanced reward systems appropriately recognize research quality, integrity, teaching and mentorship'. ${ }^{104}$ When an environment that encourages quality and discourages carelessness exists, formal complaints and 'whistle blowing' would not be encountered; (3) Both researchers and their institutions are responsible for dealing appropriately with collaborations, co-authorships and conflict of interest. ${ }^{102}$ Juliano and Oxford ${ }^{107}$ remark that the "entire reward and advancement process in universities focuses on individual accomplishments rather than collaborative effort. In this system, credit is attributed largely to the team leader and not to others. Inevitably, the result is that the researchers seek to further their individual credibility, rather than necessarily attacking scientific problems in the most efficient manner'. Although this clearly isn't always true, the comment reflects the fact that publications are 'academic currency' when it comes to promotion and securing grant awards. This also relates directly to decisions as to co-authorship and the rank order of authors. The IOM has stated 'authorship of a scientific report is a responsibility as well as a privilege. It implies that a person has contributed essentially and substantially to the study and is able and willing to defend the work publicly. This does not mean that each author participated in all parts of the study, but it does mean that all authors have familiarized themselves with the general principles of all aspects of the study'. ${ }^{106}$

Collaboration with industry, in which systems of rewards and pressures differ somewhat from academe, requires further vigilance to maintain integrity. The Association of American Universities has said, 'research universities are concerned about financial conflict of interest (individual and institutional) because it strikes to the heart of the integrity of the institution and the public's confidence in that integrity'. ${ }^{108}$

Industry, that is, manufacturers of pharmaceuticals, surgical instruments, devices (implantable and non-implantable), durable medical equipment and so forth also have incentives to maintain integrity, both internal-including preserving their reputations and the ability to recruit meritorious scientists and to sell their products to a public that trusts them as a result of that reputation, and external-including the financial loss that can result from product recalls, government imposed penalties and litigations. However, it would seem that in order for a 'marriage' between academic and industry investigators to be successful, each must be aware of factors beyond the science that the other must live with, namely 'publish or perish' on the one hand and 'capture the market share' on the other, and not allow these influences, particularly 'marketing' to researchers and practioners to stain the process or the products of discovery. ${ }^{109,110}$

In either arena, scientists have the responsibility to ensure that their data are clearly and accurately recorded and reported so that others can attempt to reproduce the data and that errors are corrected when they are recognized. Editors of scientific journals also share in these responsibilities. ${ }^{104}$

Regarding the responsibilities of scientific journals, the IOM has stated, they must be alert for 'repetitive publications, supernumerary authorship, institutional fulfillment of responsibilities for disclosure and notification of research misconduct in publication, the use and misuse of pre-publication peer review and the appropriate response to suspicions or confirmations of misconduct in published works or works submitted for publication'. ${ }^{106}$ Journals also have an obligation to publish retractions of published reports that have been found erroneous by the original authors or that has been declared fraudulent by appropriate authorities at the research institutions. ${ }^{106}$ The International Committee of Medical Journal Editors (ICMJE) has now incorporated these recommendations into their Uniform Requirements for Manuscripts. Journals enrolled by the ICMJE must follow those requirements before a manuscript will be accepted for publication. The requirements also include registering the investigation with clinicaltrials.gov or similar registry before enrollment of subjects and thereby agreeing to report trials with negative results to the registry. ${ }^{111}$ The following of these requirements has now been specified by the FDA for all investigations needing FDA approval. ${ }^{112}$

In this role, scientific journals can be viewed as a final portal as scientific information passes from discovery to dissemination and thus an important part of the preservation of medical ethics.

As dissemination passes into practice in which scientific discoveries are applied to people who need them, it becomes the responsibility of the practitioners to use the information and products in the ways in which their safety and efficacy have been proven in accordance with the laws and codes that reflect the ethics of their communities.

This becomes a major concern in which applications of discoveries are anxiously awaited and their application begins before safety and efficacy are fully known. Often this is done under the rubric of translational science in an effort to move knowledge from the bench to the bedside rapidly. Although support for that aspiration might well be universal, it has become apparent in recent times that the desire to find a cure for SCI as soon as possible has allowed some people who have little or no credibility as research scientists to proceed to offer to persons with SCI treatments that have shown no evidence that the information learned in the laboratory can now be translated to humans and worse yet, that the safety of such treatments has not yet been fully assessed. This deviation from the recommendations offered by the ICCP becomes egregious when vast sums of money are charged for the 'treatments'. Clearly, more research is needed, both in the laboratory and at the bedside, conducted according to the ICCP Guidelines so that safe effective treatments can one day be applied for all persons with SCI. ${ }^{113}$

\section{Conclusion}

The history of medical ethics dates back to even before the time of Hippocrates and although the topic has undergone changes to conform to prevailing times and cultures, it can be said that certain virtues of the human spirit have prevailed through it all: concern for the best interests of 
the patient, applying the best, most efficacious and appropriate treatment available and above all, maintaining honesty in the discovery, dissemination and application of knowledge.

In the words of Henry David Thoreau (1816-1862): 'Rather than love, than money, than fame, give me truth'.

\section{Conflict of interest}

The author declares no conflict of interest.

\section{Acknowledgements}

This work was supported in part by funds from grant H133N0600003 from the National Institute on Disability and Rehabilitation Research in the Office of Special Education and Rehabilitation Services in the US Department of Education.

\section{References}

1 Macintyre AC. A Short History of Ethics. Routledge: London, 1998, pp 11-14.

2 Ethics Updates-Classic Texts in Ethics. [online] 2008 [cited 29 December 2009]. (Available from http://ethics.sandiego.edu/ resources/books/books.asp).

3 Bowker J. God a Brief History, Vol. 56. Dorling Kindersley: London, 2002 p 373.

4 Hass JF. Ethical issues in rehabilitation medicine. In: DeLisa JA (ed) Rehabilitation Medicine: Principles and Practice. Lippincott Co.: Philadelphia, 1998, pp 33-43.

5 The Hippocratic Oath. National Institutes of Health. [online] 2009 [cited 30 December 2009]. (Available from http://www. nlm.nih.gov/hmd/greek/greek_oath.html).

6 McCullough LB. Hume's influence on John Gregory and the history of medical ethics. J Med Philos 1999; 24: 376-375.

7 McCullough LB. John Gregory and the invention of professional relationships in medicine. J Clin Ethics 1997; 8: 11-24.

8 McCullough LB. John Gregory and the Invention of Professional Medical Ethics and the Profession of Academic Medicine. Kluwer Academic: Boston, 1998, pp 1-14.

9 Markel, H. History of medicine: on the Hippocratic Oath. New Engl J Med 2004; 350: 2026.

$10 \mathrm{Katz}$ J. The Nuremberg Code and the Nuremberg trial-a reappraisal. JAMA 1996; 276: 1662-1666.

11 Leake CD. Percival's Medical Ethics. Robert E Krieger Publishing Co.: Huntington, NY, 1975; p 76.

12 Code of Ethics of the American Medical Association (1847). Encyclopedia of Bioethics Vol. 5. In: Reich WT (ed) Simon \& Schuster Macmillan: New York, NY, 1995 pp 2637-2644.

13 Harkness, JM. Nuremberg and the issue of wartime experiments on US prisoners - the Green Committee. JAMA 1996; 276: 1672-1675.

14 Grodin MA, Annas GJ. Legacies of Nuremberg-medical ethics and human rights. JAMA 1996; 276: 1682-1683.

15 Trials of War Criminals Before the Nuremberg Military Tribunal, under Control Council 10, vol. 2: Military Tribunal, Case 1, United States v Karl Brandt et al., October 1946-April 1949 US Government Printing Office: Washington, DC, 1950.

16 The Nuremberg Code. JAMA 1996; 276: 1691.

17 Barondess JA. Medicine against society - lessons from the Third Reich. JAMA 1996; 276: 1657-1661.

18 Sidel VW. The social responsibilities of health professionals: lessons from their role in Nazi Germany. JAMA 1996; 276: $1679-1681$.
19 Horsman H. Race and Manifest Destiny: The Origins of American Racial Anglo-Saxonism. Harvard University Press: Cambridge, MA, 1981; 12: 241.

20 Bradley J. The Imperial Cruise. Little Brown and Co.: New York, 2009, pp 11-60.

21 Baron JH. The Anglo-American Biomedical Antecedents of Nazi Crimes: An Historical Analysis of Racism, Nationalism, Eugenics and Genocide 2007. Edwin Mellon Press: Lewiston NY.

22 Katz J. The consent principle of the Nuremberg Code: its significance then and now. In: Annas GJ, Grodin MA (eds) The Nazi Doctors and the Nuremberg Code. Oxford University Press: New York, NY, 1992, p 236.

23 World Medical Association: Declaration of Helsinki. $\mathrm{Br}$ Med J 1964; 2: 177-180.

24 Frankel HL. Ethical considerations in treatment and research in spinal injuries. Paraplegia 1975; 12: 242-245.

25 Carlson RV, Boyd KM, Webb DJ. The revision of the Declaration of Helsinki: past, present and future. Br J Clin Pharmacol 2004; 57: 695-713.

26 Bankert E, Amdur RJ. Institutional Review Board 2007, pp 1-230.

27 Christie B. Doctors revise Declaration of Helsinki. Br Med J 2000; 32: 913.

28 International Conference on Harmonization of Technological Requirements for Registration of Pharmaceuticals for Human Use. Guideline Good Clin Pract, E6(R1) 1996, pp 1-53.

29 Jones J. Bad Blood: The Tuskegee Syphilis Experiment: A Tragedy of Race and Medicine. The Free Press: New York, NY, 1981.

30 The National commission for the Protection of Human Subjects of Biomedical and Behavioral Research. The Belmont Report. Ethical Principles and Guidelines for the Protection of Human Subjects of Research. [Online] 1979 [cited 29 December 2009]. (Available from http://ohsr.od.nih.gov/guidelines/belmont.html).

31 Department of Health and Human Services. Code of Federal Regulations (45CFR46). [Online] 2005 [cited 29 December 2009]. (Available from http://www.hhs.gov/ohrp/humansubjects/ guidance/ $45 \mathrm{cfr} 46 . \mathrm{htm})$.

32 The Health Research Extension Act of 1985 Public Law. Statutory Basis for Title 45 Code of Federal Regulations Part 46 Protection of Human Subjects 99-158 [Online] [cited 29 December 2009]. (Available from http://www.hhs.gov/ohrp/ humansubjects/guidance/statute.htm).

33 Fawcett JW, Curt A, Steeves JD, Coleman WP, Tuszynski MH, Lamertse D et al. Guidelines for the conduct of clinical trials for spinal cord injury as developed by the ICCP panel: spontaneous recovery after spinal cord injury and statistical power needed for therapeutic clinical trials. Spinal Cord 2007; 45: 190-205.

34 Steeves JD, Lamertse D, Curt A, Fawcett JW, Tuszynski MH, Ditunno JF et al. Guidelines for the conduct of clinical trials for spinal cord injury as developed by the ICCP panel: clinical trial outcome measures. Spinal Cord 2007; 45: 206-221.

35 Tuszynski MH, Steeves JD, Fawcett JW, Lamertse D, Kalichman $\mathrm{M}$, Rask $\mathrm{C}$ et al. Guidelines for the conduct of clinical trials for spinal cord injury (SCI) as developed by the ICCP panel: clinical trial inclusion/exclusion criteria and ethics. Spinal Cord 2007; 45: 222-231.

36 Lamertse D, Tuszynski MH, Steeves JD, Curt A, Fawcett JW, Rask $\mathrm{C}$ et al. Guidelines for the conduct of clinical trials for spinal cord injury (SCI) as developed by the ICCP panel: clinical trial design. Spinal Cord 2007; 45: 232-242.

37 Etziony MB. The Physician's Creed. CC Thomas: Springfield, IL, 1978.

38 Levy A, Ohry A. The physician's oath today: necessity or anachronism. Med Law 1987; 6: 219-225.

39 McCullough LB. Historical perspectives on the ethical dimensions of the patient-physician relationship: the medical ethics of John Gregory. Ethics Sci Med 1978; 5: 47-53.

40 Macciocchi SN, Stringer AY. Assessing risk and harm: the convergence of ethical and empirical considerations. Arch Phys Med Rehabil 2001; 82: S15-S19.

41 Council on Ethical and Judicial Affairs. AMA Code of Medical Ethics. American Medical Association: Chicago, 1997. 
42 Dunkas N. The Works of Hippocrates. Diachronic Publications, Inc.: Athens, 1998, pp 11-19.

43 The World Medical Association. Physicians' Oath, [online] 1948 [cited 30 December 2009]. (Available from http://www.cirp.org/ library/ethics/geneva/).

44 Jones DA. The Hippocratic Oath. The Declaration of Geneva and other modern adaptations of the Classical Doctors' Oath. Catholic Med Q, 2006: 1.

45 Seidleman WE. The path to Nuremberg in the pages of JAMA, 1933-1939. JAMA 1996; 276: 1693-1696.

46 Kater M. Doctors Under Hitler. University of North Carolina Press: Chapel Hill, 1989.

47 Constitution of the World Health Organization [Online] 1946 [cited 1 June 2010]. (Available from http://apps.who.int/gb/bd/ $\mathrm{PDF} / \mathrm{bd} 47 / \mathrm{EN} /$ constitution-en.pdf).

48 The Universal Declaration of Human Rights [Online] 1948 [cited 21 May 2010]. (Available from http:// www.un.org/en/ documents/udhr/).

49 Nutton V. What's in an oath? J R Coll Physicians Lond 1928; 29: $159-166$.

50 Orr RD, Pang N, Pellegrino ED, Siegler M. The use of the Hippocratic oath: a review of 20th century practice and a content analysis of oaths administered in medical schools in the United States and Canada in 1993. J Clin Ethics 1997; 8: 377-388.

51 Smith DC. The Hippocratic oath and modern medicine. J Hist Med Allied Sci 1996; 51: 484-500.

52 General Medical Council: Good Medical Practice [Online] 2009 [cited 30 December 2009]. (Available from http://www. gmc-uk.org/guidance/index.asp).

53 Council on Ethical and Judicial Affairs. AMA Code of Medical Ethics. American Medical Association: Chicago, 1997.

54 Pelligrino ED. Medical ethics, education and the physician's image. JAMA 1976; 235: 1043-1044.

55 Biering-Sorenson F. International perspectives on spinal cord injury care. In Lin V (ed), Spinal Cord Medicine Principles and Practice 2010. Publication Services, Inc.: Champaign, IL, (in press).

56 Donovan WH, Carter RE, Wilkerson MA. A profile of denials of durable medical equipment for SCI patients by third party payers. Am J Phys Med 1987; 66: 238-243.

57 Crane AB. Taking the offensive against claims denials. Hosp Health Netw 2007; 81: 46-50.

58 Kroken P. Reducing medical necessity denials. Radiol Manage 2006; 28: 35-37.

59 Donovan WH. On Health Insurance, [Online] 2009 [cited 23 February 2010]. (Available from http://essaysbywhd.blogspot. $\mathrm{com} /$ ).

60 Walsh P. Tetraplegics and the justice of resource allocation. Paraplegia 1993; 31: 143-146.

61 Kirschner KL, Stocking C, Wagner LB, Foyer SJ, Siegler M. Arch Phys Med Rehabil 2001; 82: S2-S8.

62 Nando-Tewarie RS, Hurtado A, Bartels RH, Grotenhuis A, Oudega M. Stem cell-based therapies for spinal cord injury. I Spinal Cord Med 2009; 32: 105-114.

63 Ramer LM, Ramer MS, Steeves JD. Setting the stage for functional repair of spinal cord injuries: a cast of thousands. Spinal Cord 2005; 43: 134-161.

64 Kwon BK, Hillyer J, Tetzlaff W. Translational research in spinal cord injury: a survey of opinion from the SCI community. J Neurotrauma 2010; 27: 21-33.

65 Krason S, Hollberg W. The law and history of abortion: the Supreme Court Refuted (1984) American Government Course Manual. Seton Home Study Sch 2000, p 194.

66 Potts M, Campbell M. History of contraception. In: Sciarra JJ (ed) Gynecology \& Obstretics 2002. Lippincott Williams and Wilkins: Philadelphia, Chap 8, pp 1-23.

67 History of Abortion [Online] 2009. [cited 30 December 2009]. (Available from http://en.wikipedia.org/wiki/History of abortion).

68 Streitmater R. Voices of Revolution 2001. Columbia University Press: New York, p 169

69 Wilke JC. Impose morality? In: Why Can't We Love Them Both? Heritage house: Victoria, BC, 2006, p 30
70 Gordon SB. Law and everyday death: infanticide and the backlash against women's rights after the civil war. In: Sarat A, Douglas L, Umphery M (eds). 2006. University of Michigan Press: Ann Arbor, MI, p 67.

71 Seidelman WE. The path to Nuremberg in the pages of JAMA. JAMA 1996; 276: 1693-1696.

72 Heredity and race. Foreign letters, from our regular correspondent, Berlin. JAMA 1939; 113: 434

73 Roe v Wade, 410 US (1973).

74 Watson JD, Crick F. The molecular structure of nucleic acids: a structure for deoxyribose nucleic acid. Nature 1953; 171: 737-738.

75 Rahman A, Katsive L, Henshaw SK. A global review of laws on induced abortion, 1985-1997. Int Family Plan Perspect 1998; 24: $56-64$.

76 Donovan WH. On the Right to Life, [Online] 2009 [cited 23 February 2010]. (Available from http://essaysbywhd.blogspot.com/).

77 Chevalier Z, Kennedy P, Sherlock O. Spinal cord injury, coping and psychological adjustment: a literature review. Spinal Cord 2009; 47: 778-782.

78 Sakakibara BM, Miller WC, Orenczuk SG, Wolfe DL, The SCIRE Research Team. A systematic review of depression and anxiety measures used with individuals with spinal cord injury. Spinal Cord 2009; 47: 841-851.

79 Ohry A. Ethical questions in the treatment of spinal cord injured patients. Paraplegia 1987; 25: 293-295.

80 Kennedy P, Sherlock O, McClelland M, Short D, Royle D, Wilson C. A multi-centre study of the community needs of people with spinal cord injuries: the irst 18 months. Spinal Cord 2010; 48: 15-20.

81 DeVivo MJ, Black KJ, Richards JS, Stover SL. Suicide following spinal cord injury. Paraplegia 1991; 29: 620-627.

82 National Spinal Cord Injury Statistical Center. Annual Report 2009. University of Alabama: Birmingham, 2010, p 26.

83 Bodenhamer E, Archterberg-Lawlis J, Kevorkian G, Belonus A, Cofer J. Staff and patient perceptions of the psychosocial concerns of spinal cord injured persons. Am J Phys Med 1983; 62: 182-193.

84 Classification of Euthanasia. Encyclopedia [Online]. 2009 [cited 3 January 2010]. (Available from http://en.wikipedia.org/wiki/ euthanasia).

85 Harris NM. The euthanasia debate. J R Army Med Corps 2001; 147: 367-370.

86 Council on Ethical and Judicial Affairs. AMA Code of Medical Ethics. American Medical Association: Chicago, 1997, pp 39-55.

87 Harvath TA. Voluntary refusal of food and fluids: attitudes of Oregon hospice nurses and social workers. Int J Palliat Nurs 2004; 10: 236-241.

88 Emanuel EJ. A review of the ethical and legal aspects of terminating medical care. Am J Med 1988; 84: 291-301.

89 Quill TE. Terri Schiavo-a tragedy compounded. N Engl J Med 2005; 352: 1630-1633.

90 In re Doe, 16 Phila. 229, 1987 Phila Cty. Rptr. LEXIS 30 (1987).

91 FAQ's about Death with Dignity. www.oregon.gov. [Online 2009]. [cited 3 January 2010]. (Available from http://www. oregon.gov/DHS/ph/pas/faqs.shtml\#insurance).

92 Batavia AI. The ethics of PAS: morally prevalent relationships between personal assistance services and physician assisted suicide. Arch Phys Med Rehabil 2001; 82: S25-S31.

93 Chin AE, Hedberg K, Higginson GK, Flemming DW. Legalized physician-assisted suicide in Oregon - the first year's experience. N Engl J Med 1999; 340: 577-583.

94 Baravia AI. Disability and physician-assisted suicide. N Engl J Med 1997; 336: 1671-1673.

95 Otlokski M. Voluntary Euthanasia and the Common Law. Oxford University Press: Oxford, UK, 1997, pp 175-177.

96 Cullen PV. A Stranger in Blood: The Case Files on Dr John Bodkin Adams. Elliott \& Thompson: London, 2006.

97 History of Euthanasia. [online] 2009 [cited 4 January 2010]. (Available from www.euthanasia.com http://www.euthanasia. com/historyeuthanasia.html).

98 Detwiler DS. Germany: A Short History, 2nd edn. Carbondale and Edwardsville, IL, 1989, pp 198-201.

99 Burleigh M. Death and Deliverence: Euthanasia in Germany. Cambridge University Press: Cambridge, 1994, pp 1900-1945. 
100 Ending the Life of a Newborn: The Gronigen Protocol: Introduction [online] 2009 [cited 4 January 2010]. (Available from http:// www.medscape/viewarticle/569471).

101 Hinman LM. Academic integrity and the world wide web. Comp Soc 2002; 32: 33-35.

102 Office of Research Integrity. RCR - Points for Discussion., [online] 2008 [cited 22 Feb 2010]. (Available from http://ori.hhs.gov/ education/point_all.shtml).

103 King J. The scientific endeavor is based on vigilance, not trust. Sci Engineer Ethics 1999; 5: 215-217.

104 National Academy of Sciences, National Academy of Engineering, Institute of Medicine. Responsible Science: Ensuring the Integrity of the Research Process, Vol. 1. National Academy Press: Washington, DC, 1992, pp 1-35.

105 The Scientific Research Society. Honor in Science. Sigma Xi, 1997, p 18.

106 The Institute of Medicine. The Responsible Conduct of Research in the Health Sciences. The National Academy Press: Washington, DC, 1989, p 31, 34, 37, 38, 87.
107 Juliano RL, Oxford GS. Critical issues in PhD training for biomedical scientists. Acad Med 2001; 76: 1005-1012.

108 Task Force on Research Accountability. Report on Individual and Institutional Financial Conflict of Interest. Association of American Universities, 2001, pp i, ii.

109 Goehl TJ. Embracing Scrutiny. Environ Health Perspect 2004; 112: A788.

110 Weber LJ, Wayland MT, Holton B. Health care professionals and industry: reducing conflicts of interest and established best practices. Arch Phys Med Rehabil 2001; 82: S20-S24.

111 Drazen JM, Van Der Weyden MB, Sahni P, Rosenberg J, Marusic A, Laine $\mathrm{C}$ et al. Uniform format for disclosure of competing interests in ICMJE journals. CMAJ 2009; 27: 565.

112 Food and Drug Administration. Federal Register, vol. 72, No. 238, 12 December 2007. Notices 70594.

113 Chhabra HS, Lima C, Sachdeva S, Mittal A, Nigam V, Chaturvedi D et al. Autologous mucosal transplant in chronic spinal cord injury: an Indian pilot study. Spinal Cord 47: 887-895. 